\title{
SECURITY EDUCATION IN DANGEROUS TIMES
}

\author{
Prof. Andrzej PIECZYWOK, PhD \\ Kazimierz Wielki University, Bydgoszcz, Poland
}

\begin{abstract}
The article is concerned with the problems of Security Education in the context of threats to man's existence. The aim of the article is to present the possibilities of Security Education from processual and technical (educational) aspects to prevent threats. The main research objective adopted by the author is: What are the main threats to mankind and how are they prevented by Security Education? The main focus is on the problems of education and threats to mankind. The article consists of an introduction outlining the significance of the subject. The most typical threats to man's security and how Security Education could prevent them are described later.
\end{abstract}

Keywords: threat, security, Security Education, feeling of security

\section{Introduction}

Mankind has struggled with many threats connected with everyday existence since the dawn of time. These threats existed in the search for food and in man defending himself from wild animals, other men etc. Knowledge gained through own experience and through observation of other people was used by man in his defence. It is in primeval society that we can see the first elements of Security Education. In response to the challenges posed by globalisation in the developing world by the hazards and development of civilisation and the transformation of societies, a significant role has been assigned to education. Education demonstrates how to benefit from the modern world and how to define danger and undertake 
action minimising its negative effects. Education is part of the development of society as a whole and each human being; it inspires and stimulates action.

Education is a key social process and a dynamic element subject to change. It plays an important role in the life of each man. Its dilemmas can be traced down to the changes of attitudes and behaviour of human collectives because, in a fast changing culture, technology and economics contradict basic moral and ethical norms and especially those of culture and tradition. The multitude of work and responsibilities and the fast pace of life mean that more and more people suffer from various kinds of health conditions and mental disturbances which can result in excessive aggression, hypersensitivity, mistrust, fears, suspicions and a wish to retaliate or take revenge. At present, education is being used more and more to search for various solutions for these dilemmas and man's imperfections. Modern education strives to enrich the education process with multimedia solutions introducing modern technologies. Therefore, not only the formula of education but also its content are indispensable in order to develop human personality effectively, provide knowledge, skills and competences to live among other people. This includes care and education, socialisation and training, teaching, learning and self-improvement.

Education, as well as each other areas of human activity in society, is transformed with the changes of conditions in which it is achieved. The directions of those changes are either determined by educational ideas or result naturally from changes in social and technological conditions accompanying education. The problem of how to educate man so that he can achieve the fullness of his life's capabilities, what kind of background he should receive in childhood to lead a secure life and also be well prepared (educated) and resourceful, has existed for a long time. In the past, it was believed that paedagogical efforts should be directed towards man in his youth, but when man is already a well-formed adult, it is a duty to act for his good. Today, this approach is no longer valid. In today's reality, we believe that man is shaped from birth to death, which also makes adults targets of paedagogical activity. Security Education is, therefore, continual through the course of human life. However, we see that in the sphere of education, the creative person in these processes is changing. In childhood, these are third persons - parents, teachers or other people important for a child. In adulthood, self-development is more 
emphasised - it is individuals themselves who develop self-education processes so necessary to prevent threats.

Security Education, due to various institutional and extra institutional activities for the security of man, leads him along the paths of various forms and methods, helps him to discover and enhance his assets and work on improving on his weak points. A specific role is here assigned to parents and teachers who are directly responsible for the multifaceted development of a child (alumnus, student). Parents undertake the most difficult and hardest task which is to educate a small child to become a worthy, responsible man able to coexist and cooperate in society. Parents are those who most of all satisfy the basic biological and psychic needs of a child. First of all, they satisfy the need for love and acceptance, give the feeling of security and also develop new cognitive, emotional and social needs, the need for friendship, recognition and self-realisation.

Coming back to teachers, it must be emphasised that they ought to perceive their profession not as an occupation but a mission. A good teacher is a teacher who is aware of his role. The model of a teacher as a professional is only complete when he exercises practical activity to improve his workplace. At this point, however, the above ideal clashes with the reality of everyday life. We observe many social threats to education such as the excessive amount of responsibilities (especially those not pertaining directly to work with a student i.e. administration, filing documents etc.) together with relatively low remuneration, exposure to high stress levels and professional burn out. Another problem in the teaching profession seems to be motivation for further work, effort, development clashing with everyday routine, monotony and excessive daily duties.

The school of today operates in a highly competitive market. The 19th century Prussian education model no longer works. It is falling apart before our eyes. A young man can find more attractive ways to spend time than school learning. A boring school always loses out to the Internet. Even TV, meeting peers and sport are interesting enough to make students spend less time on formal learning.

The aim of the article is to present the possibilities of Security Education from a processual and workroom aspect (educational aspect) in order to prevent threats to human space. The main research problem formulated by the Author is "What are the main threats for man and how does Security Education prevent 
them?" The article uses mainly theoretical methods concerning analysis and synthesis of the subject and also comparative methods. The content of the article includes problems from many academic fields such as paedegaogics of security, axiology, and the anthropology of man, psychology of threats, epistemology, and praxeology. The article consists of an introduction outlining the significance of the subject. The most typical threats to human security and how Security Education can prevent them are described later .

\section{Contemporary threats to man}

One of the greatest hazards in our civilisation is disregard for experience and existing organised procedures in dealing with threats. Now we could list a large number of threats with their epithets even to the level of absurdity, but today's list may prove out of date tomorrow. Therefore, we should not focus on prediction of threats but on working out procedures and tools to eliminate or neutralise their negative effects. One of the greatest threats to civilisation is the inability to organise collective counteraction to threats. Threats to national existence or territorial sovereignty are not any weaker. Economic, political and social threats are growing and restrict sovereignty (see Luczak 2005, pp. 40-41). This demonstrates that traditional state instruments such as military forces must evolve together or even earlier than the threats in order to meet those challenges.

Each new modernising activity or innovation has its specific social, economic or cultural effects. The experience in introducing the idea of information society demonstrates that besides the assumed positive effects, there are also evidently negative ones influencing both society and individuals. These threats are new forms of stratifying society ${ }^{1}$ that is layering it according to the access to information, education and qualifications. Negative effects include such criminal acts as hacking, spreading racist ideas and child pornography, propagating terrorism and the activity of sects etc. Stanisław Lem pointed out, in relation to

1 Słownik Języka Polskiego (1981, p.346) Stratification (in the sociological meaning) - differentiating strata in society according to different criteria, for example the level of income or possessions, social positions, common way of living, lifestyle etc. 
the Internet, "man`s inborn inclination to cheating and dishonesty can flourish with the net. Where there are no prohibitions, lying is allowed" (Lem 2000, p. 166). Another danger is addiction, especially of the young, so called screen generation, to the interactive Internet (Cwalina 2001, pp. 29-42) and this group manifests such characteristic features as: being engrossed in the world of computer games, a limited ability to concentrate, and difficulty in social relations.

The development of the information technology society may create threats including 1) the area of politics: the temptation of information totalitarianism (state monopoly), vulnerability to information interference, sense of limited freedom and privacy; 2) in the area of social life: dehumanisation, alienation, deluge of fake information, restriction of privacy by easier and more extensive control; 3 ) in the sphere of economics: possible conflicts in automation and robotisation, employment reduction, increased requirements in the operation of automated systems, excessive standardisation of products and services, the possibility of new crime; 4) in the sphere of education and knowledge: diverse access to knowledge, the need for ongoing education, plagiarism, breach of copy rights; 5) in the sphere of work: increased unemployment because of automation of some work stations, decrease in employment in industry and agriculture; 6) in the sphere of health care: dehumanisation of health services, extra medical use of information about health condition, new civilisational diseases, and unequal access to medical help (Globan-Klas and Sienkiewicz 1999, pp. 139-157).

The changing processes in education are being discussed against the background of globalisation, which is something essentially different from the international flow of ideas, goods or people existing for centuries before. At present, technology is "tightening" space and time and, we could say, reducing their significance; we are witnessing a change in human activity worldwide and we may speak about its globalisation in many aspects. Globalisation appeared initially in the area of economics. Abolition of regulations and barriers on the financial markets enhanced by the progress of computer technology made all economies dependent on the flow of increasing capital. At the same time, due to advances in telecommunications, global economy involved unprecedented coordination of production in many countries.

With respect to risk posed for individuals, organisations and societies by uncertainty and the unpredictable nature of the modern world, modernity is defined as "society 
of risk". In this context, it is also possible to observe the negative consequences of constant learning, which consists in unequal opportunities for education, unequal access to sources of knowledge and a variety of competences. What matters in the risk society is distribution of opportunities or risk, particularly when considering the influence of education on social allocation of individuals in the course of their lives. Intentional learning becomes a differentiating factor in individuals' adaptation to changing reality in both the work environment and other spheres of social life. Educational paths in social and professional structures in computer society are more and more controlled by the demands of the market, but they are also individual and always involve social implications. It follows from the analysis of contemporary threats that they are an integral part of our lives and cannot be eliminated but only brought to a socially acceptable level. Generally speaking, the socially acceptable threats are those which do not introduce destruction into our lives. The level of security is subjective and, therefore, it must be defined from the point of view of socially accepted threats (Czupryński 2012, p.17). At present, everything can be a threat and may also be a factor supporting man's development. It means that man as a subject and object of security is a creator of threats. Analysis of the kinds of threats suggests that they may be grouped according to the criteria of sources of conflict and the character of the effects they cause. Therefore, threats may be divided into the following categories: politicalmilitary, socio-economic and ecological-nature related (Czupryński 2012, p. 21).

Political and military threats follow from confrontational politics which may escalate and lead to military conflict. In the past, the sources of warfare were considered to be as follows: unsatisfied human desires, biological features and human nature, the character of great leaders, prejudice, superstitions and ignorance - low level of social development, conflicts among groups of people, "clash of civilisations", rivalry among political groups - hostile intentions and many others quoted by experts in various historical periods (cf. Grotius 1957, Aron 1995). The main classical threats posed by a country include: the character of its politics, organisation and mobilisation methods of the army, its efficiency and effectiveness of action, and economic capability of the country to conduct wars. The mentioned factors can be defined for each country. The creator of asymmetrical threats in the international arena may not always be a legal subject (Madej 2007, pp. 32-68). The source of threat may be a criminal or an unaccepted political or economic organisation with unpredictable objectives, methods and 
motives of action. However, such organisations should not be endowed with the rights to achieve their goals through warfare because this right in the international arena is only ascribed to legal subjects.

Terrorism, particularly due to action against innocent people, poses a serious threat to national security, democratic values and the rights and freedom of citizens.

Therefore, it is necessary to make every effort to minimalise the threat of terrorist attacks in the Polish Republic. This can only be achieved by creation of clear and transparent rules of action for all forces and institutions partaking in the defence against terrorism and also by proper education in the subject. Due to all the negative effects of terrorism, it was necessary to reconsider challenges especially by modifying the approach to crisis management and the effective use of types and methods of Security Education. It is from this reflection that the possibilities and significance of Security Education follow, as well as the prestige of the modern management of man's security.

The main objective of the article pertaining to the relations and dependencies between terrorist challenges and threats was formed with respect to the character and destination of some services and knowledge (skills) of public administration workers in crisis management. The challenges are the theory and practice of Security Education as well the quality of crisis management. The threats are obviously the effects of terrorism. The concept of cyberwar is becoming more and more important in the modern world even though some people consider it a distant future. The essential features of cyberwar are: information advantage, the invisible foe, the area of operation - cyberspace and critical factor - time (Sienkiewicz 2004). Information security is an important element of national, regional and group security. If a hypothetical enemy starts operations that block the national system and such operations are carried out by a hypothetical legal subject in the international arena, such a threat must be considered a war threat because operations are conducted against the state apparatus. The threat to so called critical technological infrastructure is an important threat to internal state security (Łuczak 2005). The critical technological infrastructure includes: tele information systems, bank, energy, ecology systems, water intake points and facilities connected with external security. In highly developed states, the 
very thing which their pride becomes a threat if not properly secured by special measures.

Socio-economic threats are the result of low social and economic level of development and inequalities between information technology society and industrial or rural society (see Toffler and Toffler 1997). The source of the threats is the perceived disproportions and claims with respect to the whole world. The source of socio-economic threats in developed countries is failing democracy and the collapse of trust funds and insurance companies. Threats also arise from openness to immigrants and failure to meet their expectations.

Another problem is social conflicts resulting from growing unemployment and redundancies in traditional raw material branches and very little need for those workers in the new economy. Benjamin Barber defines this phenomenon as the need for a virtual worker, a fully programmed worker, who is to work 24 hours a day without food, with minimal cost of conservation" (Barber 1997, pp. 35-36). Experts in the field point out that new technologies, apart from their positive aspects, may be used for such secret operations as manipulation. These threats may be used by various groups of interest with access and the possibility to apply those methods. Based on their potential, they may influence a society by creating a desirable social behaviour.

Threat to socio-economic security is social pathology. This area of problems is vast and differentiated and, therefore, no general scientific theory was formulated in spite of many years of research (Borowski and Kłosowska 2010, p. 31). According to W. Okoń (2007, p. 299), social pathology is a science about reasons, symptoms and attempts to eliminate such "deviations" of social behaviour as criminal acts, alcohol abuse, drug abuse etc.

Finally, social pathology is defined as a negative social phenomenon fulfilling the following conditions:

1. breach of social values and norms;

2. destructive behaviour measured by the scale of social condemnation;

3. presence in large societies or even on a mass scale;

4. need to use collective effort to oppose it and fight it.

(Pospiszyl 2008, p. 12) 
Summing up, social pathology is a behaviour which disturbs social balance and is non-compliant with generally accepted norms and values. The causes of pathological behaviour are many. Some of them are: micro damage to the brain during delivery and then lack of proper upbringing, or influence of society and its influence on an individual. The most popular pathological phenomena in Poland are alcohol abuse, drug abuse, crime and other pathological phenomena such as sexual deviation, suicide and prostitution.

Ecological threats come from inappropriate management of natural resources and imprudent changes in natural environment. Negative effects of forces of nature are often attributed to nature, while we must not forget that it is man who can become by his actions independent of disasters and catastrophes. Good management of funds and safeguarding investments securing personal and collective security can liberate man from the negative effects of natural forces. The task forces coming from the military forces supporting home office and administration are allocated to fight the negative effects of the forces of nature. The military forces participate in such actions only to support and their operational capabilities are neither the result nor are built to eliminate the effects of the action of forces of nature.

The threats listed in the literature on the subject include demographic, geographic, technological, economic and socio-cultural threats (see Ficoń 2007, p. 107). All mentioned sources cause - each in its own way- degradation of the natural environment and, thus, a threat to the life, health and social security of people. A growing number of people inhabiting the territory of Poland, including those coming as immigrants from authoritarian and totalitarian countries, may upset the natural balance and self-purification processes of nature. In turn, discrepancy between the amount of natural resources necessary for human life and real needs on a certain geographical area is perceived as an ecological geographical threat. This situation has its consequences in increased environmental pollution in the location where the resources are acquired. Enormous amounts of waste are produced which cannot be dealt with by the natural environment. Ecological technological threats rise mostly from obsolete technologies used in Poland, producing a large amount of carbon dioxide and polluting the atmosphere. The sources of those threats are connected with ecologically uncomfortable production for highly developed countries that are located in Poland. These phenomena combined with a deficit of resources in Poland as a developing country 
bring down the level of its ecological security. Ecological socio-cultural threats, resulting from fast civilisation development with simultaneous underinvestment of natural environment protection, may also be dangerous for our country. The most hazardous phenomena reducing ecological security is the greenhouse effect, ozone layer depletion, acid rain and smog. It is also worth mentioning that ecological threats may be a serious danger for the food economy and may cause serious damage to the body's system, even leading to deaths.

Ecological threats may be caused both by man's activity and natural factors. They are defined as a kind of threat which may pose a hazard for living creatures as a result of changes in the natural environment (Słownik terminów z zakresu bezpieczeństwa narodowego 2008, p.89). The quoted definition may be compared with another based on the term "ecological catastrophe"2 Ecological catastrophe is a lasting (naturally irreversible) damage or destruction of a large natural environment area adversely influencing the health and often life of people in a direct or indirect way. Such events may include the following natural factors (Jakubczak and Flis eds 2006, p. 97):

- uncontrolled exploitation of natural resources (forest clearing, excessive hunting of animals, wasteful extraction of minerals);

- mass water pollution, air and soil pollution;

- lack of public, industrial and nuclear waste disposal management;

- dangerous industrial technology leading to changes in atmosphere (depletion of ozone layer, global warming, increase of ultraviolet radiation);

- natural catastrophes and industrial disruption of water relationships in the environment (reversal of river flow, lack of rational forest economy) leading to soil erosion, landslides and desertification;

- chaotic urbanisation;

- nuclear tests and tests of new types of weapon (e.g. geophysical, meteorological).

2 Ecological catastrophe - lasting (naturally irreversible) damage or destruction of a large natural environment area influencing adversely in a direct or indirect way the health and often life of people" (Nowa Encyklopedia powszechna 2010). Another model may be a definition of ecological security understood as "security of natural environment against such its use and degradation which may as its consequence threat human and social existence." 
The second group of ecological threats resulting from human activity are extraordinary threats which can be industrial catastrophes and large failures (e.g. Nuclear power plant in Chernobyl in 1986), fire in petrol refineries etc. The sources of these threats are not only in Poland but also from elsewhere. They usually threaten human life and environment, posing a serious danger to man for many years. These types of threat are very dangerous because they occur suddenly causing immediate degradation of the natural environment and danger for man and for living natural resources.

\section{Security Education in modern times}

Based on the presented threats, we may speak about global challenges facing education. Education becomes a valuable "commodity" on the market of goods. Social orientation in education is changing. A diploma and the abilities achieved become a desirable value. Continuous learning assumes a specific role in the world of dynamic changes in all areas of life. It is related, on the one hand, to the needs and educational aspirations of individuals and, on the other, to the needs of the economy. Its competitiveness and effectiveness and the level and quality of life of individuals and welfare of regions depends more and more, apart from such factors as work, capital and land, on the world of modern technology and advanced communication technology, on economic, technical knowledge and social sciences.

In the modern world, people with no adequate competence, specific cultural capital, access to information or lacking so called market power become more and more affected by marginalisation caused by unemployment, inability to articulate their own interests, functional illiteracy and other social phenomena.

Security Education has a particular significance in the creation of an appropriate approach and values, gaining knowledge and skills in preventing threats. It is an important part of the didactic-educational process and preventive actions directed mainly at civil education, communicative education and pro-health and ecological education. It is also considered an indispensable element of education and preparation for work and life in modern conditions. It first appears in the family and later is constantly modified under the influence of mass media, school, 
peer group and self-education. Many changes in the defence awareness of people are caused by concrete security conditions both external and internal. General life conditions, the level of political, military threats, public security, social threats etc. are also significant

Security Education has a long history and evolved from preparation of young people for defence against military threats. Though Security Education and education for defence are often identified, education for security is connected with developing awareness, motivation and behaviour in the event of threats which have a much broader scale. Security Education is, on the one hand, a theoretical process with such factors as people (teachers, students) and substantial factors (objectives, content, principles of education, forms and methods, didactic resources), on the other hand, it consists in practical actions developing man's security - influences his attitudes, values, knowledge and skills necessary to prevent threats, dealing with them in hazardous situations and eliminating their effects. Security Education is also helpful in enlarging knowledge. Its simplest form is sensual (by means of sight, smell, hearing and touch). Next is mental knowledge (based on concepts, judgments and conclusions) and empirical knowledge through experience (acting) (Smarzyński 1985).

Security Education includes many cognitive and empirical areas which have been frequently analysed. It consists of many didactic-educational processes including education and training and education in a broad meaning in order to prepare young people and adults for situations threatening their life and the functioning of the state. The most important listed problem areas (areas of research) are challenges and threats as well as the subjective and objective structure of security. There are also new areas in Security Education research - these include, among others, defining the essence and legitimacy of respecting the tolerance of man to risk and uncertainty, developing skills for dealing with one's own and other people`s emotions, widening the vision of man entangled and exposed to threats. Security Education is one of the ways to fight the growing wave of accidents, threats and low culture of security. It is focussed on creating and developing the sense of personal responsibility, not only for one`s own health and life, but most of all for that of other people, as well as making people realise and develop the conviction that each man is responsible and has an impact on the condition of security. 
Security Education has an important role in the system of preventing the effects of natural and technological disasters. Each event defined as disaster - be it earthquake or serious accident in an industrial establishment - is connected with heavy burden on those concerned. Unique circumstances and the suddenness of events trigger a set of psychological reactions both on the physiological level ( e.g. quickened heartbeat, convulsions) cognitive ( narrowing down of attention, problems in decision making) emotional (anger, fear, helplessness) and behavioural (arousal, fight or escape). The potential of Security Education in its personal and structural aspects has a significant place in both the theory and practice of various institutions. When systematically carried out by means of various types and methods of training, it may considerably contribute to the growth of effective transmission of knowledge about security, among other places, in schools, work establishments and the media, which has a great impact on preparing young people and adults for rational behaviour in the face of civilisational, social and military hazards and for their active participation in defence enterprises conducted by state administration, territorial self-government and social organisations.

Security Education of a modern man must be based on general human values, national, social or personal. They nourish the need to defend peace, protect the environment, and pursue some principles in life. Values are always inseparable from needs, which are one of the most important categories in Security Education. Needs are essential motives of action to achieve the desired values, namely positively defined actual states of things under certain conditions. The degree and range of their fulfilment is constituent for the existence and development of the subject. Not every value is desirable considering both capabilities of a subject (lack of purchasing power) and its usefulness (value perceived but useless, not essential for living, survival and development $)^{3}$ because if a value is a conscious and expected feature of something or somebody, it needs to be kept. It also breeds the feeling of lack of desire to fill it. Needs can pertain to material, social, cultural spiritual and intellectual values indispensable for the functioning of a social group and formalised organisations developed by people.

3 Dobrowolski and Wróbel (1987, p. 100) elaborate on this issue classifying political needs as rational and irrational; real and ideal, true and false and intellectual and extra intellectual. 


\section{Conclusions}

Security Education must meet the challenges of the 21st century. The given possibilities of Security Education to create safe realms for man's existence should constantly be modified and reconsidered in the changing reality and society developed to be able to learn continuously and to implement this knowledge.

A new model of Security Education requires a change in the method of education and its basis "a new culture of learning". Its essence should be independent learning as a result of undertaken research activity. A modern educational entity should become a learning institution using the intellectual potential of both teachers, tutors and students and enable effective learning, exploring and understanding of modern reality.

The method of teaching and the content must be remodelled. According to M. Spitzer, the methods of teaching applied today in most schools do not allow learning in compliance with the brain (Spitzer 2007). The Internet generation learns differently than their parents. They make decisions quicker, are open to innovation, prefer multi-task activities and have perfect eye-hand coordination.

It is not justified to treat school as the only and most important place where children and youth gain basic knowledge. Informal education has flourished for over a decade. The evidence is innumerable projects and classes creatively developing children's passions and interests. Education is an important social, economic and political investment. Education and the competence of people become the most important values of modern computer technology civilisation and societies based on knowledge. Security Education should be an ongoing process aimed at possible multifaceted development of personality and general intellectual ability. Man achieves his humanity by perfecting his personality through broadening knowledge. Knowledge, skills and his moral and spiritual values are important in themselves and are connected with realisation of his potential.

More emphasis should be made on developing young people's ability to recognise broad threats and danger around them. A new theory of Security Education and its methodology are needed. Intuition is not enough and the processes of Security Education should be praxeologically designed. The elements of education including moral, cognitive, emotional, operational and substantial element should 
be defined. There should be time and place in Security Education to develop awareness in people of possible terrorist attacks, conflicts, wars. Educational institutions should focus on transmission of solid knowledge about hazards of contemporary world, developing the approach of civil vigilance, demonstrating a wide context of conditions of national and international security. It is necessary to develop in people the awareness of generic and ideological variety and eliminate the attitudes of intolerance and xenophobia, developing a culture of peace which is the basis of man's security.

\section{References}

Aron, R., 1995. Pokój i wojna między narodami (teoria). Wyd. Adama Smitha, Warsaw. Barber, B. R., 1997. Dżihad kontra McŚwiat. Muza, Warsaw.

Borowski, M. E. and Kłosowska, E., 2010. Alkoholizm jako rodzaj patologii spotecznej. Oficyna Wydawnicza Wyżzzej Szkoły im. Pawła Włodkowica, Płock.

Cwalina, W., 2001. Generacja Y- ponury mit czy obiecująca rzeczywistość. In T. Zasępa (ed.) Internet - Fenomen spoteczeństwa informacyjnego. Wyd. Świętego Pawła, Lublin.

Czupryński, A., (ed.) 2012. Inżynieria bezpieczeństwa sit. AON, Warsaw.

Dobrowolski, P. S. and Wróbel, S., 1987. Wprowadzenie do nauki o polityce. Wyd. Krytyki Politycznej, Katowice.

Ficoń, K., 2007. Inżynieria zarzadzania kryzysowego, podejście systemowe. Bel Studio, Warsaw.

Globan-Klas, T. and Sienkiewicz, P., 1999. Społeczeństwo informacyjne: szanse izagrożenia.

Wyd. Fundacji Postępu Telekomunikacji, Kraków.

Grotius, H., 1957. O prawie wojny i pokoju. Vol. 1. PWN, Warsaw.

Jakubczak, R. and Flis, J. (eds), 2006. Bezpieczeństwo narodowe Polski w XXI wieku.

Bellona, Warsaw.

Lem, S., 2000. Świat na krawędzi. Wyd. Literackie, Kraków.

Łuczak, W., 2005. Strategiczny przegląd obronny państwa. Zagrożenia - oczami ekspertów. In Raport Wojsko-Technika-Obronność, 2005.

Madej, M., 2007. Zagrożenia asymetryczne bezpieczeństwa państw obszaru transatlantyckiego. Polski Instytut Spraw Międzynarodowych, Warsaw.

Nowa Encyklopedia powszechna PWN (multimedia). 2010. Warsaw.

Okoń, W., 2007. Nowy stownik pedagogiczny. Wyd. Akademickie „Żak”, Warsaw.

Pospiszyl, I., 2008. Patologie spoteczne. PWN, Warsaw.

Sienkiewicz, P., 2004. Wizje i model wojny informacyjnej. AGH, Kraków. 
Smarzyński, H., 1985. Podstawowe zagadnienia dydaktyki szkoły wyższej. PWN, WarsawKraków.

Stownik Języka Polskiego. vol. 3. 1981. PWN, Warsaw.

Stownik terminów z zakresu bezpieczeństwa narodowego. 2008. AON, Warsaw.

Spitzer, M., 2007. Jak uczy się mózg? PWN, Warsaw.

Toffler, A. and Toffler, H., 1997. Wojna $i$ antywojna. Wyd. Literackie, Warsaw. 